\title{
Social Dialogue in Public Sector Reflection about Hungarian and Slovenian approach
}

\author{
UDK: $304: 35: 331.526$

\section{Zvone Vodovnik} \\ Univerza v Ljubljani, Fakulteta za upravo \\ zvone.vodovnik@fu.uni-lj.si \\ Aniko Noemi Turi \\ aniko-noemi.turi@gmx.co.uk
}

\begin{abstract}
The process of last years expended enlargement of the European Union leads EU governmental bodies towards enacting new European documents. These documents must be considered as legal bases for making the EU the most dynamic and competitive economy in the world being capable of sustainable economic growth with more and better jobs and greater social cohesion. In the area of the EU legislation the social dialogue must be regarded as an important issue. For time being the EU documents regulate some elements of social dialogue in private sector however, the social dialogue in public sector is still outside of the EU regulation.

The paper elaborates a comparative view between two Member States such as Hungary and Slovenia by exploring and analyzing EU industrial relations, and the relationship between the industrial relations of these Member States. It is evident that the EU enlargement has further increased this diversity, and the EU industrial relations in many parts distinguish from national industrial relations. This article analyses the process of the legislative activities at the EU legislative bodies, as well as in the national legislations of Hungary and Slovenia. It emphasizes also the concept of EU industrial relations and shows, which are the frames of the social dialogue in public sector of Hungary and Slovenia.
\end{abstract}

Key words: social dialogue, Public sector, European union, Hungary, Slovenia, labour law, International Regulation, International Labour Organization 


\section{Introduction}

As a starting point of any reflection of the harmonization of industrial relations in $\mathrm{EU}$ and possible improvements of single elements of regulations, it is necessary to have an insight into the differences of the labour relations systems of the different Member States.

Despite some convergent trends and a general process towards decentralization by the enlargements, the national industrial relations are characterized by diversity in the Member States. The significant differences can be found in trade union density, and the coverage, as well as the structures of collective bargaining. This refers to the interactions between the social partners, cross-industry and sectoral levels that shape in different levels of collective agreements, bargaining and mechanism of conflict resolutions. The EU labour law as a legal dimension is a part of the harmonization of the different Member States' labour law.

The EU industrial relation, as a dimension of the industrial relations that is situated above the national industrial relations, is responsible to constitute new and common European industrial relations. Its principal aim is to get separated from the national industrial relations, and to reach a higher level.

The social dialogue, as a product of the process of the Europeanization of labour relation, is highlighting instances where the social dialogue has had an impact on working conditions. The impact of social dialogue on working conditions is considered at all levels, namely, sectoral, company and workplace levels. In the process of the convergence of employment relations regulation of private sector and public sector the social dialogue is gaining an important role also in the public sector.

After having presented the wider historical background of employment relations in $\mathrm{EU}$ and the two countries the article elaborates the thesis that there exist different approaches to the social dialogue and especially the social dialogue in public sector in the Member States. Diversity of the regulations may be the advantage in search of ways for improvements of regulation of this area. 
Zvone Vodovnik, Aniko Noemi Turi

Social Dialogue in Public Sector

Reflection about Hungarian and Slovenian approach

\section{International Regulation of Social Dialogue in Public Sector}

\subsection{International Labour Organization and social dialogue in public sector}

The guideline for the legislature in the area of social dialogue could be somewhat important, however abstract the ILO documents. The area of social dialogue in the public sector in modern states including Slovenia - could be successfully regulated if ILO Convention 150, 1978 (Labour Administration) and ILO Convention 151, 1978 (Labour Relations in Public Service) were taken into account. The first Convention provides to states the impetus to transfer a certain degree of state authority in the area of labour to civil society institutions, whereas the second convention requires that states develop and regulate "soft" methods of conflict prevention and conflict resolution in the public sector in their respective legislations. As reported in literature such an approach has been widely used, e.g. in Great Britain. Some British institutions (e.g. the HSC and Acas) were formed when functions previously performed by government departments were spun off to independent bodies. The relevant department, however, retains mechanisms of influence through funding, appointments, target setting, audit and review (Dickens, Neal, 2006; Bevan 1992).

The constitutional requirements and problems of their implementation must be observed also from the perspective of international law. It is important to note that the essential subjects of the employment law in both sectors, such as wage systems, collective bargaining, and the regulation of strikes, are not subjects of regulation in the European Union. On the other hand, ILO directly or indirectly addresses these questions in its regulations. It is possible to conclude that ILO regulations deal with these questions less than it could be expected, considering the importance of these matters in the modern world. There is a contradiction between the regulatory approach of ILO and EU. Differences in culture as well as in economic and social development are legitimate grounds for international organizations to abstain from the regulation of a specific subject. Regarding the social dialogue, this area of communication and social relations could be easier regulated within EU than within ILO, because $\mathrm{EU}$ is much more homogeneous than the whole world. From the point of view of industrial democracy and the doctrine of industrial relations, the lack of provisions in EU regulations with regard to social dialogue, with the exception of 
Zvone Vodovnik, Aniko Noemi Turi

Social Dialogue in Public Sector

Reflection about Hungarian and Slovenian approach

workers' direct participation, is not acceptable. At least the European Council legal acts do contain some regulation concerning the social dialogue (the European Social Charter). The interpretations of its provisions by the competent bodies of the organization are also important. ${ }^{1}$

\subsection{European social dialogue}

EU industrial relations and its dimension gave a new common European dimension of EU law. EU industrial relations are multifaceted and relate to the interactions between the European social partners at cross- industry sectoral levels. The two cornerstones of employment and social policies are the European Employment Strategy on job creation and labour market reform strategies, and a Social Agenda designed to ensure that the benefits of EU growth reaches everyone in society and every region of EU. The principle of subsidiarity (cf. article $5 \mathrm{EC}$ ) is fundamental to the evaluation and content of EU labour law.

Other aspects of national rights are principally excluded from EU competence (cf. article 137.5 EC) such as the right of association, the right of strike, pay, and the right to impose lock-outs.

The European Union provides major impetus for the convergence of Community and national policies through the method of open co-ordination. In this way EU labour law is aiming at partial harmonization of the different labour law models in the Member States, result of which is a European social model. This EU model, recognized by EU institutions is edified by democracy, individual rights, collective bargaining, the market economy, equality of opportunity and flexicurity. The power and interaction between the social partners within the framework of social dialogue, the European Employment Strategy, the open method of coordination, worker participation, and information and consultation form part of the EU industrial relations.

From the European legislative point of view, the legal regulation of the European Community contains two principles. The above mentioned sudsidiarity means that "in areas which do not fall within its exclusive competence, the

1 They are providing criteria for the interpretation of the legal position of social partners in this area. Expert bodies of the ILO also play an important role in the process of the implementation of even basic labour standards concerned in countries with the no tradition of industrial democracy like African countries (Fashoyin, 2006). 
Community shall take action", and the principle of proportionality means that the Community "shall not go beyond what is necessary to achieve the objectives" of the Treaty. ${ }^{2}$

In 1985 the European level-social dialogue was initiated and supported by the Commission. This means an integration of social partners into the legislative machinery, because the trade unions as well as Employers' Associations of the member states do have inter-professional roof organizations on European level.

Today social dialogue takes place on both, at cross-industry and sectoral level. On workers' side ETUC (European Trade Union Congress) is representing employees, and employers are represented by UNICE (Union des Confédération de I'Industrie et des Employeurs d'Europe) and CEEP (Centre of Enterprises with Public Participation and of Enterprise of General Economic Interest).

Article 138 and 139 of the EC Treaty is based on the promotion of the consultation of management and labour at Community level. Article 139 of the EC Treaty results the contractual relations and the European collective agreements, namely the agreements on part-time work, telework, parental leave, fixed-term work, work-related stress, and harassment and violence at work.

According to the Article 139.2 of the EC Treaty the European collective agreement can be implemented in accordance with procedures and practices specific to management and labour and the member state, or these can be implemented both, through a decision by the Council and a directive.

European collective agreements can also cover collective agreements and other contractual relations between social partners in transnational European companies. ${ }^{3}$ Amsterdam Treaty adopted the Employment Title and the European Employment Strategy (EES) with the goal to promote a skilled, trained

\footnotetext{
2 Distinction between the two principles can be seen also between primary and secondary law. Primary law is contained in the Treaty and the secondary law is enacted on the basis of the Treaty main instruments being Regulations and Directives. Regulation without any kind of transformation shall be binding in its entirety and directly applicable in the member states. Directive is considered as a more flexible instrument than Regulation, and at the same time more important instrument in the diversity of the member states' legislative frameworks.
}

3 Weiss 2006, p. 10 
Zvone Vodovnik, Aniko Noemi Turi

Social Dialogue in Public Sector

Reflection about Hungarian and Slovenian approach

and adaptable workforce, as well as labour markets responsive to economic change. ${ }^{4}$

Open method coordination (OMC) is also the EES's achievement. Its added value is described as convergence, country surveillance, subsidiarity, management by objectives and integrated approach. According to Article 137.2 of the EC Treaty open method coordination gained importance as a primary method meaning in addition to hard law that the focus to an increasing extent has to be on soft law. The basic strategy is the OMC institutionalizing a mutual learning process by search for best practices.

Directives concerning worker participation, information, and consultation, show that EU labour law clearly emphasizes the harmonization of rules regarding information and consultation. Directive 98/596EC concerns collective dismissals, 94/45/EC is about the European works councils. We can find provisions regarding transfers of undertakings in the directive 2001/23/EC and to European Company Statute in the 2001/21/EC and 2001/86/EC.

The process of European integration has already indicated that a more diverse Community is unable to go forward by the traditional institutional structure. It is evident that a common constitutional framework is needed for EU. ${ }^{\boldsymbol{5}}$

The Treaty of Lisbon, known as Reform Treaty as well, would alter the functioning of EU through a series of amendments to the Treaty on European Union, Treaty establishing the European Community and the Treaty on the Functioning of the European Union. The two consolidated treaties would form the legal basis of the Union, and combined constitute most of the content of the rejected European Constitution. The Lisbon Treaty is scheduled to be ratified by the end of 2008, as of May 23, 2008 fourteen countries have finished ratification.

4 EES built on Employment Guidelines, National Action Plans, Joint Employment Report and Recommendations.

The Employment Guideline that was adopted before Amsterdam Treaty came into four pillars: employability, adaptability, entrepreneurship, and equal opportunities.

5 The Constitutional Treaty, establishing a Constitution of Europe (TCE), commonly referred to as the European Constitution was an unimplemented international treaty intended to create a constitution for the European Union. TCE was signed in Rome by the representatives of the member states on 29 October 2004, when French and Dutch voters rejected the treaty in referenda. Following the period of reflection, the European Council in June 2007 decided to start negotiations on a Reform Treaty as a replacement. 


\section{Employment relations in private and public sector}

From the point of view of the individual employment relationship, there are no systematic or comprehensive approaches, because most of the legislative acts of EU member states only set minimum conditions in favor of the employees. By the process of Europeanization of labour relations, in the private sector, the most important achievements have been reached in the area of the collective employment relations. Namely it is the area of the involvement of employees in management's decision making. In this field, EC developed two strategies: 1) to establish a minimum framework for information and consultation in the Member States and 2) to establish systems of employee involvement in trans-nationally operating undertakings and groups of undertakings.

There are some Directives, which set up the minimum standards of the member states, such as, safeguarding of employees' rights, or establishing information and consultations procedures that have to meet several requirements. Information and consultation has to take place on decisions likely to lead to substantial changes in work organisation or in contractual relations in private as well as in public sector.

Hungary has passed the deep political and economic transformation since the collapse of its former state socialist regimes in the late 1980's, which can be seen in the light of progress towards democracy and accession to EU in May 2004. By means of the legal harmonization of EU, the collective bargaining at the sectoral level, as the major development in the beginning of 2006, was a ministerial decree in the extension of the newly concluded agreement in the construction sector. The coverage rate of single-employer agreements remained $30 \%$, while the proportion of employees covered directly by sectoral agreements grew from $9 \%$ to $15 \%{ }^{6}$

During the legislative development, another recurring issue was the creation of legal foundation for national and sectoral social dialogue and in this respect the regulation of representativeness of the social partner organisations. The social partners in the inter-professional social dialogue are not only

6 In regard to legislative developments, the most outstanding changes of the Hungarian labour law occurred in the field of the regulation of public sector employment, which assisted the government in its attempt to streamline public administration and to reduce the budget deficit. 
Zvone Vodovnik, Aniko Noemi Turi

Social Dialogue in Public Sector

Reflection about Hungarian and Slovenian approach

integrated into the machinery of the legislation, but they are also entitled to conclude voluntary agreements. The voluntary framework agreements are an offer for the actors on national scale to give them some guidance and to enrich their apprehension. Sectoral social dialogue, in addition to the interprofessional social dialogue, was not very successful in producing framework agreements. The sectoral dialogue's main goal may be to coordinate in a better way the collective bargaining in the Member States. Also it may to improve the vertical dialogue between European actors and national actors for a multi-level structure in all the sectors.

For an example in Hungary, after a long but fruitful discussion with the social partners, the government submitted to the Parliament the bills of the tripartite national forum, the National Interest Reconciliation Council, established in 1988, (Országos Érdekegyeztető Tanács, OÉT), the Sectoral Social Dialogue Committees (Ágazati Párbeszéd Bizottságok), and other aspects of social dialogue. In the organization of social partners there were no meaningful changes. Therewith there is no considerable change since 1992, in balance between legislation and either collective bargaining.

In regard to legislative developments, the most outstanding changes of the Hungarian labour law occurred in the field of the regulation of public sector employment as a matter of fact. This work will focus on the new changes in the industrial relations related to the Hungarian Labour Code's amendments according to EU legal harmonization, and developments of the social dialogue in the country.

Workers' freedom of association rights in Hungary have been considerably strengthened since free elections were held in 1990, but Hungary also has consistently faced criticisms that it has failed to adequately implement existing labour laws, according to trade unions and organizations that monitor freedom of association rights. From a legal perspective, Hungary has the basic framework for workers' freedom of association protections in place.

The Constitution (Act XX. of 1949) protects workers' rights in both the private and public sectors to form and join unions by the article 63 and also the right to strike by the article 70/C (1), (2). Collective bargaining rights are secured by statute. In 1957, Hungary ratified both ILO Convention 87, concerning freedom of association, and Convention 98 on the Right to Organize and Collective Bargaining. Moreover, in the years leading up to 2004, when it joined the European Union, Hungary took a number of measures to improve workers' rights including increasing some penalties and enacting a groundbreaking equal 
rights law that offers some prospect of improving protections for union members. Hungary's Constitution guarantees also the right to establish or join trade unions "to protect and represent the interests of employees." The Labour Code, article 15(1) and Act II of 1989 on the Right of Association, article 1 ensure workers' rights to form and join unions.

From the point of view of Slovenia, it is a country which has also undergone fundamental social and political transition in the last two decades. After introducing political democracy, the privatization of the means of production, and a market economy the reorganization processes also affected the state structures and employment relations. All these changes have a political and social basis in the new Constitution adopted in 1991. The Constitution introduced new principles to the Slovene legal system and stressed the common European values. The majority of these already existed before the transition, whereas some were introduced as a consequence of political changes. ${ }^{7}$ Along with the profound social changes, it was necessary to adapt the state organization to modern standards. This ambition of the Slovene people went along with the intentions of Slovenia to enter European political and economic integrations. $^{8}$

In the process of preparations to make this step, Slovenia accepted the acquis communautaire, which means that it obliged itself to make necessary legal and other changes to harmonize with European Union Member States. In this process, the legal regulation of employment relations was improved. The principle of the legal regulation of minimal standards of working conditions by statute was introduced into the legal system; however other areas regarding the regulation of working conditions were left to contractual regulations. This was the beginning of a rapid development of collective employment relations through the activities of emerging social partners and their social dialogue (Vodovnik, 2006).

The principle of the "soft law" regulation of working conditions was not introduced only in the private sector but also in the public sector. ${ }^{\mathbf{9}}$ It was a consequence of the traditional Slovene legislative orientation towards

7 Slovenia has made the fastest social and economic progress among the countries in transition. Today, Slovenia's economic growth is nearly the European average and the country suffers from a shortage of manpower.

8 Slovenia joined the European Council in 1993 and was among the first countries of Central and Eastern Europe to join the European Union in 2004.

9 "Soft law" is the expression which means that the single area of social and economic relations my be regulated by the autonomous legal resources like collective agreements. 
Zvone Vodovnik, Aniko Noemi Turi

Social Dialogue in Public Sector

Reflection about Hungarian and Slovenian approach

strengthening the principle of the uniformity of employment relations in the private and the public sectors. At the same time, the fact that these two areas of employment relations cannot be regulated entirely in the same manner was taken into account. The legislature paid attention to the need to protect the public interest and to ensure the functioning of the state and local governmental bodies on one hand, and the execution of public services on the other. On these bases, the legislature has made reservations for the authoritative regulation of certain elements of the legal position of employees (Kerševan, 2005, Tičar 2005). Very few of these exceptions were made in the area of public services, many more, however, were made in the area of the employment relations of civil servants in state and local governmental bodies. The latter was left to the contractual regulation of individual and collective employment relations. The social dialogue was therefore introduced in both areas of the Slovene public sector. Similar happened in other European countries in transition. (Rychli , Pritzer, 2002).

\section{Social Dialogue in Public Sector}

\subsection{General remarks}

In Hungary the composition and operation of European works councils introduced in 1992, but mainly pointing out importance of EWCs at multi-national companies.

Actually, EWCs are new phenomenon in Hungary, as it became mandatory only when Hungary joined EU to invite representatives of Hungarian employees to the bodies working at the European company headquarters or to set up EWCs at the few multi-national companies headquartered in Hungary.

Hungary's most important long-term objective after joining EU is the increase of economic growth and employment. In order to achieve this, however, a stable macro-economic environment has to be created and long term, sustainable financial balance ensured. Three-fold strategy is in the focus of the strategy of the government: restore macro-economic balance, implement the reform process covering the entire operation of the state and work out and implement a comprehensive development policy.

The industrial relation of the public sector in Hungary can, on the whole, be considered well-organized. Institutions of consultation and negotiation are 
well developed. An important feature is the large number of agreements substituting upper-level collective agreements. It is also important for the development of industrial relations that the representativeness of trade unions is measured by membership. In Hungary, the Interest Reconciliation Council of Budgetary Institutions (IRCBI) was the most important forum of the national level interest reconciliation of public servants. Questions specifically concerning public servants or rather the whole public sector were handled by IRCBI, while more general questions were arranged by Interest Reconciliation Council (IRC). Besides employee and governmental representatives the forum included the associations of local governments and representatives of the institutions as employers; however, this latter side did not have the right to vote. During its seven years of operation IRCBI concentrated on the questions concerning public servants, and rarely dealt with issues related to the labour relations of civil servants and employees of "professional" status.

One third of the items on the agenda of plenary sessions dealt with salaries and the system of classification in which fields $|R C B|$ concluded 12 agreements. As a result of the breaking-up of public sector employment status, the Forum for the Conciliation of Interest of Public Servants (FCIPS) was established in July 1993. FCIPS was a four-sided organisation as well, its stable governmental, trade union and local government groups were fully authorised to conduct negotiation. The fourth group composed of the Hungarian Chamber of Public Administration (later the Body of Public Administration) and the National Union of Chief Municipal Officers had only consultative rights. FCIPS was empowered with the right of consultation, opinion and recommendation, while its decision making power was limited to internal procedural matters. Besides these two national forums (IRC, FCIPS) every ministry operated forum or lower level departmental forum where employer and employee representatives and in some cases NGO organisations worked. Two basic types of forum were formed at the ministry level: the bipartite interest reconciliation council in which trade unions had discussions and consultations with the leaders of the ministry. These forums endeavoured to make agreements mainly in connection with salaries and working conditions (for instance the Council for Reconciliation of Interest of Home Affairs (CRIHA) and the Council for Reconciliation of Interest of the Hungarian Army. The multilateral interest reconciliation forum including NGOs which discussed, in addition to questions concerning working conditions, professional questions as well (for instance the Council for the Reconciliation of Interests in Public Education or the Social Council). 
Zvone Vodovnik, Aniko Noemi Turi

Social Dialogue in Public Sector

Reflection about Hungarian and Slovenian approach

The government reorganised the system of interest reconciliation and created new forum starting in 1999.

In the system of social dialogue - operated between 1999 -2002 - the role of consultation was emphasized because the government took decision making completely under its own authority, while social partners demanded tools to enforce their own interests. The objective of the new government in 2002 was the establishment of a system of uniform public sector employment status and the creation of a consultation forum dealing with questions covering the entire public sector and competent to consult with the government regarding questions of standardised employment relations. In accordance with these objectives the National Council for the Reconciliation of Interests in Public Services (NCRIPS) was established which is nowadays the highest forum for interest reconciliation in the whole public sector.

The development of regions brings great changes and novelties to the organization of the public sector and to the legal regulation of this field in Slovenia (Vlaj, 2007).

These developments concern all fields of law, including the field of labour relations. In view of the fact that the new conception of regions as organizational forms in the public sector is placed between a central state organizational structure on one hand, and the more localized area of the public sector, on the other, the question is raised who will carry out the tasks, and in what manner, due to which regions are being established and what their legal position will be in this new legal organizational form. Regions will be territorial units in which various organizations in the public and private sectors will carry out special tasks determined by law (Trpin, 2004, Bohinc, 2005).

The interests of employers and employees in the field of labour relations in organizations and at other levels of the social dialogue are not the same. Their interests can be the opposite in the short-term and regarding individual matters, however, they are directed towards the same direction in the longterm and in their foundation. A fundamental interest of both is the success of an organization from which all benefit. Due to oppositions and incompatibilities of interests, mechanisms that can effectively prevent and resolve disputes must be regulated and maintained in the system of labour relations. These mechanisms must be regulated so that they can effectively serve their purpose at all levels at which communication between the social partners occurs, either as co-deciding or as concluding collective agreements regarding work or other collective agreements. Mechanisms for the prevention and resolution of 
disputes are contained in regulations which regulate or support individual types of social dialogue; however, it must be taken into consideration that in Slovenia this subject has not yet been regulated on the whole.

In EU, there is an increasing need for a better coordination of collective bargaining policy. This policy would be an important tool for the integration of EU. Despite the endeavor in this field, the results are very modest. It means that the social actors should act more efficient, and the interactions between actors and the European sectoral social dialogues should be more efficient as well.

Prevention and resolution of disputes is an important issue in the area of collective employment relations in public sector. Before a more detailed presentation of the mechanisms which serve this goal and before consideration of the question whether it is possible to formulate these mechanisms effectively and logically also at regional levels, attention must be drawn to a distinction between legal and interest disputes which may arise between social partners (Novak, 2004). This distinction is important because a method which can be applied or which is most appropriate for resolving a dispute depends on the nature of the dispute. ${ }^{\mathbf{1 0}}$ Legal disputes are disputes which arise between the participants to collective bargaining and the content of such disputes is a disagreement whether there exists a certain right or obligation on the part of any of the parties or participants to the collective agreements, whereas interest disputes are disputes which arise if one side does not accept the proposal of another side regarding the regulation of a certain question by the collective agreement, and both sides wish that such be regulated, upon their proposal, with the help of the intervention of a third party. In the field of collective bargaining in the private sector, the methods of mediation, conciliation, and arbitration can be applied for the resolution of both types of disputes. The same methods could in principle be applied in the public sector if collective

10 This distinction is not appropriately executed in the Collective Agreements Act of 2006, in which methods for different consideration of disputes are not appropriately distinguished. Most of all it must be noted that the "bargaining" which is mentioned in the Act as a method for resolving legal disputes is not a possible method for resolving such disputes. This can also importantly influence problems which refer to resolving collective labour disputes in the public sector. In accordance with the Collective Agreements Act, a system of collective bargaining in the public sector is namely separated from the system of collective agreements and collective bargaining in the private sector. In addition, such system is not regulated on the whole. Certain key elements of the system of the legal regulation of collective bargaining in the public sector are not regulated. Consequently, there can be found gaps in the law which must be filled by applying the principles of legal analogy and thereby inappropriate solutions from a general regulation are transferred to the sphere of social dialogue in the public sector. 
Zvone Vodovnik, Aniko Noemi Turi

Social Dialogue in Public Sector

Reflection about Hungarian and Slovenian approach

bargaining were entirely voluntary. However, due to the fact that collective bargaining is envisaged as an obligation in the system of the regulation of employee relations and its outcome as a key and necessary element of the legal regulation of employee relations, the situation in this field is different. In cases in which no agreement is reached, the state regulates such questions authoritatively, which cannot have a positive influence on the relations between the state and trade unions. In comparative law there are solutions stipulating that in such cases "forced arbitration" is applied for the regulation of an urgent question (Brien, 2006, Bordogna, 2006). In some systems this method is also applied for the resolution of disputes which arise in cases of a strike in the public sector if an inadmissible level of threat to the public interest could arise because of a strike. Also forced arbitration has its negative sides and it has been used less and less often in modern states. A system that guarantees that all matters which are in the public interest be regulated by state regulations creates the possibility that also collective bargaining in the public sector becomes entirely free (Vodovnik, 2006), whereas the question of the resolution of disputes in cases of a strike in the public sector remains open and is regulated in various manners in different legislations (Nunin, Vodovnik 2007).

A special type of collective bargaining at the national level is also the negotiation of social partners within the framework of so called "tripartite social dialogue". Such bargaining can be carried out directly between trade unions, employers, and the state, or within the framework of special tripartite bodies of social partnership. In Slovenia this body is the Economic and Social Council of the Republic of Slovenia. The principal outcome of bargaining is usually a social agreement by which the social partners agree on the main guidelines for the development of the state in the economic and social fields. In addition, the agreement serves as a basis for all policies which are carried out by social partners. From this viewpoint, the social agreement is an important document which substantially contributes to the prevention of misunderstandings and conflicts between social partners. In some states such a body functions also at levels lower than the national level (Kessler, Dickens, 2006). Such systems could in principle serve as a model for a similar regulation and implementation of social dialogue also in regions. For appropriate development in this field, the functioning of such a body should be regulated by the statute. In addition, appropriate organizational units should also be regulated which could effectively be used by the social partners in order to successfully resolve disputes at national and regional levels. 
The Hungarian public sector consists of a central and a local sector. The decentralised-offices also exist between these two sectors with the competence of performing some central government functions on the countries basis. The central government sector is accepted as a contrast of the local one, but the central government sector means different offices and law enforcement agencies of public administration.

After the collapse of the socialist regime, the labour legislation brought a new Labour Code (Act XXII of 1992) that regulates employment conditions and terms in case of private sector, government-owned enterprises, and non-profit organizations. The public sector achievements are four regulations: 1) on the legal status of public service employees (Act XXXIII. of 1992, LSPSE.), 2) on the legal status of civil servants (Act XXIII. of 1992, LSCS.), 3) on professional staff's service at the armed forces (Act LXIII of 1996, PSSAF.), 4) on the professional and contractual staff's service in the army (Act XCV of 2001, PCSSA.). LSPSE regulates the employment relationship education, health care and social work and LSCS assumed to provide regulation for civil servants at the central and local government. By the amendment of LSCS in 2001, for those manual workers in government offices who do not hold public powers, the Labour Code (LC.) regulates the terms of employment.

In Slovenia, viewing the employment relations in the public sector through the constitutional principles, the similarities of the employment relations in both sectors can be noted. In Slovenia, the legislature has been relatively successful when implementing constitutional principles in the regulations of the employment relations in the public sector. The principle of a democratic state (Article 1 of the Constitution) has been the starting point in making the social dialogue an important factor in regulating the employment relations in the public sector as well as in the private sector. The same holds true for the principle of a state governed by the rule of law (Article 2 of the Constitution), which was the basis for the extensive regulation of the employment relations in the public sector by statute and at the same time provided grounds for autonomous regulation. The principle of equality (Article 14 of the Constitution) led the legislature to make efforts to create the legal position of persons employed in the public sector as comparable as possible with persons employed in the private sector.

In the chapter of the Constitution dealing with economic and social relations, three specific rights which are the principal constitutional basis for the 
Zvone Vodovnik, Aniko Noemi Turi

Social Dialogue in Public Sector

Reflection about Hungarian and Slovenian approach

legal development of collective employment relations can be found. "The comprehension of the meaning and dimensions of these rights as well as their connection with international law are considered the essential preconditions for the correct drafting of the legal basis of the social dialogue in the public sector. The examination of the meaning of these rights for the employment relations in the public sector can therefore be a criterion for the evaluation of the existing legal regulation. On a constitutional basis, the Slovene public sector has been continuously changing from 1992 on. One important paradigm has been the aim to transfer some parts of the public sector to the private economic area. Methods of management in the private sector were introduced to the public sector where possible. The most radical changes which are important for the development of the new nature of employment relations were introduced by the Civil Servants Act of 2002 (CSA) and the Public Sector Wage System Act of 2002 (PSWSA). These acts were designed on the basis of the legislature's intention to put the employment relations in the public sector on a contractual basis to the greatest extent possible, including the introduction of a specific collective bargaining approach in the public sector. On the way to achieving this goal, the legislature adopted some regulations which can be identified as controversial. The legislature caused a too significant institutional effect on the collective contracts - some kind of legislative "overdose" in its efforts to ensure the principles of social dialogue in the public sector. The transfer of state authority was exaggerated to the extent that it endangered the public interest by paralysing the process of introducing the new wage system in the public sector. ${ }^{\mathbf{1 2}}$ With changes in PSWSA, the state arranged a new formula which should help to overcome the frozen position in the processes of collective bargaining on the wage system. The changes did not introduce any

11 The first right is the employees' right to participation in decision making (Article 75 of the Constitution). This right is rarely recognized to the employees in the public sectors of other states. In Slovene legislation, some modest forms of this right (e.g. information, consultation) are ensured to the employees in the public sector - less in state and local governmental bodies, and more in public services. The right to the freedom of trade unions (Article 76 of the Constitution) is also ensured for employees in the public sector. This right seems to be largely ensured for employees; however there are some indications that this right is formed in such a manner that certain responsibilities of the state are probably unwillingly transferred to trade unions. Right to strike is guaranteed also by the Constitution (Article 77 of the Constitution). This provision guaranteed the right to strike to all employees irrespective of the sector in which they are employed.

12 This fact soon caused conflicts among the social partners in the public sector. On the other hand, the state did not succeed in ensuring regulatory, organisational, and financial grounds for conflict prevention and conflict resolution in the public sector. This situation caused the problem of bringing the PSWSA into force. There have been serious delays in achieving results in the processes of collective bargaining. 
efficient tools from comparative law. By the statute the absent or deficient agreements should be replaced by statutory provisions or by government decisions. Such a solution is hardly sustainable from the political point of view. It would reveal that the state had to resort to its authority after being unable to play the role of a social partner democratically. ${ }^{13}$

PSWSA deals with different kind of collective contracts and also contains certain specific provisions on these collective contracts as autonomous legal sources. There is no statutorily established hierarchy among them. If different views regarding the value or use of these contracts appear, the problem can be resolved by the application of the general principles of the validity of legal sources (e.g. general - special, prior - posterior, favor laboratoris). Regarding the procedure for stipulating collective contract in the public sector, the Slovene legal framework does not determine a separate authority with its own competence to take part in the procedure on the employers' side, and the competence to accept the proposals of the unions, as is the case in Italy for example. On the employers' side, the representatives of employers, with the strictly determined authorization of the ministers or governmental bodies, take part in the process of collective bargaining.

The members of the negotiating parties on the employers' side and their representatives must also take into account the financial limits arising from the budget.

\subsection{Collective Bargaining}

The idea of developing a uniform European Collective Bargaining system was out in the early stages of EEC, but later, it turned out to be a naif conception. Collective bargaining has remained to be proposition of member states. There are some areas, such as collective bargaining, where EC does not have legislative power. ${ }^{14}$

In spite of the various regulation dimensions of employment relationships in Hungary, since 1992 there has been no considerable change in balance between legislation and collective bargaining in the liaison of industrial relations

13 Such cases are reported from different countries, i.g. Australia or South Korea. In last decade the government of the last state has been even under the pressure form the International Monetary Fond to introduce the essential methods of consultations and trade union freedom in some areas of the public sector- which was the condition for its support (O'Brien 2006, Park-Lee, 2006)

14 Weiss, 2006, p.15 
Zvone Vodovnik, Aniko Noemi Turi

Social Dialogue in Public Sector

Reflection about Hungarian and Slovenian approach

and public service employees. Rules of collective agreement are regulated by the Labour Code of 1992 and the Act on public servants.

In accordance with the whole set of the (ten previously mentioned) acts only employees covered by LSPSE and LC can conclude workplace collective agreements. Higher level collective agreements concluded at sectoral and macro-level have been discussed above. The amendments of the Mt. regarding collective agreements targeted the extension negotiations and agreements. The system changed again as a result of the LSPSE amendment of December 2004. There are two basic features of the transformation: 1. Until the end of 2008 a dual system will exist as concerns representativeness; on the one hand, representativeness based on the results of Public Servants' Councils' elections, on the other hand, it should be measured in terms of union membership; 2. The way is open to conclude sectoral collective agreements, consequently, the new article 12/A of LSPSE re-regulated the right of trade unions to conclude collective agreements based on, primarily, representativeness and, secondly, on membership. The basic problems in concluding collective agreements are the division of employers' functions and the structure of finance.

Consequently, it should be clarified during collective bargaining that questions to be laid down in the agreement can only be settled partially within the institution because as a result of the division of the employers' function the workplace director is not a competent negotiating partner. The practice that the director of the budgetary institution can not make a collective agreement individually but with the approval of the local government pushes the problems one level upwards and does not help at all to solve the problems of sectoral collective agreements. LSPSE allows collective agreements with employer's interest representation organisations as well. There is no such employer's interest representation organisation in the public sector at present. However, some so-called multi-employer collective agreements have been concluded in the past few years under the scope of LSPSE with the application of the rules of LC.

According to collective bargaining at sectoral level, the sectoral Minister, the representative trade unions and sectoral interest reconciliation forum are responsible for the agreements. They do estimate about agreements' drafts, proposals about wages and advancements. For civil servants, and for those who are occupied by service at armed forces, there is no possibility for collective bargaining neither at workplace level, nor at sectoral level. 
According to the regulation of public service employees in Hungary, the trade union has right for the collective bargaining on the workplace level. As the wage scale and budget of the public sector institutions are set by the laws, collective bargaining, in the strict legal sense, is limited to workplace level agreements.

Moreover, in government offices even workplace level bargaining is not allowed. In turn, national and sectoral negotiations on the annual wage rises are of paramount importance, which may conclude agreements between the government and trade unions. ${ }^{\mathbf{1 5}}$

The development of regions brings great changes and novelties to the organization of the public sector and to the legal regulation of this field in Slovenia. These developments concern all fields of law, including the field of labour relations. In view of the fact that the new conception of regions as organizational forms in the public sector is placed between a central state organizational structure on one hand, and the more localized area of the public sector, on the other, the question is raised who will carry out the tasks, and in what manner, due to which regions are being established and what their legal position will be in this new legal organizational form. ${ }^{\mathbf{1 6}}$

The interests of employers and employees in the field of labour relations in organizations and at other levels of the social dialogue are not the same. Their interests can be the opposite in the short-term and regarding individual matters, however, they are directed towards the same direction in the longterm and in their foundation. A fundamental interest of both is the success of an organization from which all benefit. Due to oppositions and incompatibilities of interests, mechanisms that can effectively prevent and resolve disputes must be regulated and maintained in the system of labour relations. These mechanisms must be regulated so that they can effectively serve their purpose at all levels at which communication between the social partners occurs,

15 Those trade unions command with the right of representation, which public service employees' number at the employer come up to the $10 \%$ of the number of occupied public service employees' number, or at least $2 / 3$ part of the public service employees belong to the same group or profession of employment. On a sectoral level, those trade unions have representative rights, which sectoral employees' number come up to the $10 \%$ of the number of occupied sectoral employees' number. On a national level the National Trade Union Confederation has representative right, but at least three sectoral trade unions have to be members and the union density has to amount $5 \%$ of the all public service employees.

16 Regions will be territorial units in which various organisations in the public and private sectors will carry out special tasks determined by law (Trpin, 2004, Bohinc, 2005). 
Zvone Vodovnik, Aniko Noemi Turi

Social Dialogue in Public Sector

Reflection about Hungarian and Slovenian approach

either as co-deciding or as concluding collective agreements regarding work or other collective agreements. Mechanisms for the prevention and resolution of disputes are contained in regulations which regulate or support individual types of social dialogue; however, it must be taken into consideration that in Slovenia this subject has not yet been regulated on the whole.

\section{Conflict Prevention and Resolution}

In Hungary, specialized labour courts exist, however the system of labour dispute resolution permits also a pre-court procedure, involving workplace-level conciliation, before the individual disputes get to the court. The 1967 Labour Code entitled trade unions to take a decisive part in the mandatory pre-labour court procedure for handling disputes over individual rights. Workplace-level grievances boards (munkaügyi döntöbizottságok), run by unions, and were the juridical forums of first instance in such disputes. The 1992 Labour Code thus repealed the mandatory workplace-level grievance boards, and included only a brief passage concerning a pre-court conciliation procedure between the employer and the employee. It stipulated, for example, that within 15 days of the employer taking a measure allegedly injuring the rights of an employee, the employee had the right to initiate steps and demand a conciliation process in writing. The role of trade unions in pre-court dispute resolution procedures has been narrowed to providing consultation and some legal advice for employees involved. The concept of the collective labour dispute was introduced in 1989, right after the disintegration of the state socialist regime. According to the 1992 Labour Code, there is a difference between collective dispute of interest and legal dispute.

In Hungary there is a voluntary use of mediation in collective labour disputes. The Labour Mediation and Arbitration Service (Munkaügyi Közvetítöi és Döntöbírói Szolgálat) had been set up in 1996 by the national tripartite body with the help of an EU PHARE project. The institution's goal is to harmonize the industrial relation at company, intersectoral and sectoral levels.

The Hungarian sectoral consultative forum next to National Public Service Interest Reconciliation Council is the Interest Reconciliation Council of Civil Servants that assimilates other parties such as National Body of Administration, Association of Chief Urban Municipal Officers, national trade union confederations, trade union federations and the government as well. In the sec- 
toral consultative forum, if any kind of representative disagreement occurs, in this case for the interested party's requirement in a non-litigant way the court will adjudge. The armed professional service's consultative forum is the Interministerial Interest Reconciliation Forum of Law Enforcement Organizations (Rendvédelmi Szervek Tárcaközi Érdekegyeztető Fóruma) that embodies government and national trade unions.

The separate central governmental interest reconciliation forum is responsible for civil servants to effect the agreements. In case of the legal questions in the field of civil service, wage-settings, and the budget of central and social security influencing the civil servants interests, come under the civil servant interest reconciliation forum. On the national and sectoral level the consultative forum is the National Public Service Interest Reconciliation Council (Országos Közszolgálati Érdekegyeztető Tanács), which is affected to the civil servants, public service employees and armed force professional employment status.

This institution was established in 1992, which provides an institutional framework for concluding agreements covering all the public sector employees.

As far as the content of collective contracts in the public sector is concerned, this is the weakest point of the system. In Slovenia problems related to the content of collective contracts caused a stoppage in the process of implementing PSWSA in practice. The legislature did not take a decision to regulate all wages and other minimal working conditions of employees in the public sector by statute, making the collective contracts an additional tool for extending the rights of employees. The statute declared the regulation of certain essential elements of the wage system as falling within the "competence" of social partners (the evaluation of job performance, the majority of additional payments, which are essential elements of a wage).

As already mentioned collective bargaining about the new wage system was very hard and long lasting process which has finished recently (June 2008). The delay has been a consequence of the conflict of interests among social partners in the public sector. The strong position of trade unions on one side and the temptation of state authorities to resort to the use of state power instead of bargaining, on the other, generated dangerous conflicts among social partners.

Another element is the compulsory conciliation procedure, which should arrive at solutions acceptable to both parties (Novak, 2004). The substantive limitations imposed by the statute are more rigorous for the protection of the public interest compared to private interests. The starting point of these limita- 
tions is the requirement that essential public services and the functioning of the state and other governmental bodies must be ensured and maintained. Under Slovene law, the competence to decide what kind of work activity should be considered essential is given to managers, and cases of conflicts concerning such are brought before labour court judges, both on the grounds of abstract regulations in legislation. The theory of industrial relations has already pointed out that this function is a very heavy burden for managers and for courts as well (Rose, 2006).

One of the most important rights of the industrial relations is the right of strike. In the field of public sector the major reasons of strikes are about the wage agreements. In Hungary in 2007 by the reason of difficult bargain rounds in wage-agreements, a Unified Public Service Strike Committee was formed. What is the background of this new institution? In mid 2006, the government announced its plans to introduce austere reform measures, involving significant cuts in the budget, services and staff of public institutions. The announcement met with strong resistance from the more radical trade unions,

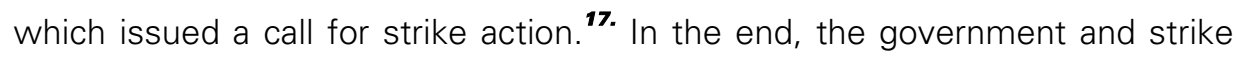
committee concluded an agreement and as a result, the strike action was immediately cancelled. According to strike regulation, public service employees have right to strike, for civil servants special rules are applied, when those occupied in service at armed forces have no right to strike.

In 2008, there was a nation-wide protest strike against of the health system privatization. Trade union confederations unanimously rejected the reform proposal, and employer organizations, on the other hand, supported the reform proposal as well. In this case, the social dialogue failed to reach consensus. However, in Hungary social dialogue for better working and safe work is in development, although in the majority of sectors, the occupational health and safety related dialogue does not exist.

EU regulations also demand a strong partnership between the government and social as well as civil actors, which further upgrades the role of Hungarian social and civil partners beyond their traditional role shaped by domestic written rules and code of conducts. The content of the discussions between the government and social partners, however, revealed the need for further

17 The president of the Trade Unions' Cooperation Forum (Szakszervezetek Együttmüködési Fóruma,) announced that the trade unions had hoped for a $6.5 \%$ gross increase in salaries. On 9 November 2006, all of the negotiating trade union confederations issued an open letter, in which they jointly condemned the fact that public sector employees would suffer a larger wage decline than other employees due to the government's austere measures. 
Zvone Vodovnik, Aniko Noemi Turi

Social Dialogue in Public Sector Reflection about Hungarian and Slovenian approach

reinforcement of the expert capacity of the social partners in order to be able to contribute more significantly.

In Slovenia, the right to strike is guaranteed also by the Constitution (Article 77 of the Constitution). This provision guarantees the right to strike to all employees irrespective of the sector in which they are employed. The provision gives to the state the right and duty to impose on employees restrictions of this right by law. In Slovene reality the Strike Act was adopted by the parliament before the new Constitution 1991 came into force.

In the Slovene legal system all employees have the right to strike. This right can be limited by statute if the protection of the public interest so requires. According to the Constitution and international standards limitations of the right to strike can be imposed on employees in the public sector as well as those in the private sector (Gernigon, et. al., 2000). The statute which regulates these limitations has already been mentioned, i.e. the Strike Act of 1991. The Act contains the procedural (formal) as well as substantive limitations. The principal formal limitation is the duty of employees who intend to strike to announce the strike within the time-limits determined by the statute. The time limits are different for the public sector compared to the private sector.

The Act has not been amended since, although certain parts cannot be applied in practice because of the constitutional requirement that those parts of former legislation which are in contradiction with the new constitutional provisions (values) may not be applied after the coming into force of the Constitution.

In the process of introducing the new role of social partners in the area of employment relations, the conflicts between them and between the individual employees and employers emerged and consequently the character of the strike also changed. Together with other methods for conflict prevention and conflict resolution in both sectors, the strike must be controlled with modern formal tools, determined by legislation. The most delicate area for the creation and application of these tools is the public sector. Considering the fact that there are no specific statutory provisions in this area, it can be concluded that the legislature did not devote enough attention to this problem. The Slovene legal system does not have any efficient mechanisms to control the legality of announced strikes. The limitations or self-limitations on strikes in collective agreements are not 
Zvone Vodovnik, Aniko Noemi Turi

Social Dialogue in Public Sector

Reflection about Hungarian and Slovenian approach

an element of the legal system. Limitations can be imposed unilaterally by general enactments of employers. There is no such institution in the Slovene system, as is known in Italy in the form of a Guarantee Commission, which has a strong position in the process of evaluating the self regulation of strikes by the collective agreements.

\section{Conclusion}

The comparative analyse of social dialogue regulation in the international law and in different EU member states points out that EU faces the need of higher degree of unification or at least harmonization of the regulation of social dialogue. EU regulation does not contain a wide range of solutions in the area of social dialogue in public sector however ILO has already enacted some important documents in support of the social dialogue in public sector. Insight in national legislation of different EU member countries enables the conclusion that there is a great diversity of approaches in national legislations. The comparison between the legal regulation of social dialogue in Hungary and Slovenia provides us with information about some similar approaches in the regulation of social dialogue in private sector of the two countries. They are more or less the consequence of the influence of EU law (e.g.. European Works Councils). A great difference can be however registered over the regulation of the social dialogue in public sector. Such differences aggravate the international basic regulation of this area by the competent EU legislative bodies. In the same time such differences may be the consequence of the international regulations. Namely EU does not provide the regulation which could be the starting point of the unification or at least harmonization of this area. The composition of the statutory regulation of the social dialogue in public sector in the two EU Member States brings to light the fact that collective bargaining in public sector is a important legal subsystem of both countries. A further analysis also presents the fact that there are great differences in ways of prevention and resolution of the collective interest disputes in public sector. This finding which has been expected enables the conclusion that the public sector employees of different countries are being in the unequal position regarding to their influence on the processes of creation of the legal regulation of their working conditions. This problem can be resold by the use of results of further comparative analyses of this area, which points on the best solutions in the practice of 
Zvone Vodovnik, Aniko Noemi Turi

Social Dialogue in Public Sector Reflection about Hungarian and Slovenian approach

some states and proposed by the theory as well. At last but not at least the important contribution to such analyses is supposed to be recognized to the activities of professional organizations which deal with the social dialogue like the International Industrial Relations Association (IIRA).

Prof. dr. Zvone Vodovnik je redni profesor za delovno pravo, socialno varnost na Fakulteti za upravo, UL, Fakulteti za management Koper, UP ter stalni zunanji sodelavec Pravne fakultete Univerze v Trstu, Pravne fakultete Univerze v Mariboru, Evropske pravne fakultete $v$ Novi Gorici in znanstveni svetnik Inštituta za delo pri Pravni fakulteti $v$ Ljubljani. Ob pedagoških in raziskovalnih aktivnostih je dalj časa opravljal funkcijo sodnika $v$ pravosodju $v$ Sloveniji od tega od 1999 do 2001 na Vrhovnem sodišču Republike Slovenije.

Aniko Noemi Turi je kandidatka za mlado raziskovalko na Fakulteti za management v Kopru za področje delovnega prava. Končala je univerzitetni program Pravo na Pravni fakulteti $v$ Szegedu na Madžarskem ter bolonjski študijski program I. stopnje Pravo na univerzi $v$ Lyonu. Na tej univerzi končuje podiplomski študijski program Pravo II. stopnje. 


\section{Bibliography}

- $\quad$ Bevan A. H., (1992): Alternative Dispute Ressolution: A Lawyer's Guide to Madiation and forms of Dispute Resolution, Sweet\&Maxwell, London.

- Bodogna, L., (2007): Moral hazard, transaction costs and the reform of public service employment relations, 8th European Congress of the International Industrial Relations Association, Manchester, UK.

- $\quad$ Bohinc, R., (2005): Osebe javnega prava: javni zavodi, javna podjetja, javne agencije, javni skladi, First Edition, GV Založba, p. 464 ,Ljubljana.

- Brien, J., (2006): Reguating and Resolving Collective Disputes in Australian Public Sector, 14th World Congress IIRA, Lima.

- Fashoyin, T., (2006): Management of Disputes in the Public Service in Southern Africa, 14th World Congress, International Industrial Relations Association, Lima.

- Gernigon, A., Odero, H., (2000): ILO Principles Concerning the Right to Strike, International Labour review, Vol. 137, No.4, str.30.

- Kántor R., (1997): A Munkaügyi Közvetítöi és Döntőbírói Szolgálat (MKDSZ) szakmai tevékenységéröl.

- Kerševan, E., (2005): Približevanje ureditve položaja javnega uslužbenca položaju delavca v zasebnem sektorju, Delavci in delodajalci, št. 2-3, letnik V, str. 392, Ljubljana.

- Ladó M., Nacsa B., Tóth F., (2001): A munkaügyi kapcsolatok, az érdekegyeztetés és a szociális párbeszéd fogalma, viszonya, jellemzői.

- Neal A. C., Dickens L. edit., 2006, The Changing Institutional Face of British Employment Relations, Kluwer Law International, Alphen aan den Rijn.

- Novak, J., (2004): Delovni spori, First Edition, GV založba, p. 487, Ljubljana.

- Rose J., (2006): Regulating and Resolving Public Sector Disputes in Canada Designation of Essential Employees, IIRA, 14th World Congress Lima.

- Tičar, B., (2005): Status javnih zavodov v javnem sektorju: pravno-ekonomska analiza. Podjet. delo, letn. 31, št. 3/4, str. 515-526, Ljubljana.

- $\quad$ Tóth F., (2007): Munkaügyi kapcsolatok. Alapfogalmak, kulcsfogalmak. Sokszorosított kézirat.

- Tóth F., (2007): Bevezetés a Munkaügyi Kapcsolatokba. Egyetemi jegyzet. SZIE. Gödöllö.

- Trpin, G., (2004): Problemi pravne ureditve javnih zavodov, in: X. Dnevi javnega prava, Portorož, 14.-16. junij 2004, Inštitut za javno upravo, pp. 169-182, Ljubljana. 
Zvone Vodovnik, Aniko Noemi Turi

Social Dialogue in Public Sector Reflection about Hungarian and Slovenian approach

- Vlaj, S., (2007): Pokrajine v Sloveniji in Evropski uniji. Javna uprava, Inštitut za javno upravo, Ljubljana.

- Vodovnik Z. (2006): Collective Disputes in the Public Sector in the Central and Eastarn European Countries (CEEC) - Notes About Basic Presumptions. Preventing and Resolving Collective Labour Disputes in Public Sector, 14th World Congress, International Industrial Relations Association, Lima.

- Vodovnik Z., Nunin R., (2007): Characteristics of the Social Dialogue in the Public Sector of Neighbouring Countries as an Incentive to International Regulation (Italy and Slovenia).

- Weiss M., (2006): The Europeanization of Industrial relations, the role of EU law, Faculty of management Koper.

Legal and other resources:

- Ustava Republike Slovenije (Uradni list RS, št. 33/1991, 42/1997, 66/2000, 23/2003, 69/2004, 68/2006).

- Zakon o evropskih svetih delavcev (Uradni list RS, št. 59/2002).

- Zakon o sistemu plač v javnem sektorju (Uradni list RS, št. 14/2006 - uradno prečiščeno besedilo, št. 68/2005, 57/2007).

- Zakon o zavodih (Uradni list RS, št. 12/1991, 17/1991, 121/1991, 55/1992, 13/1993, 66/1993, 45-I/1994, 8/1996, 18/1998, 36/2000, 127/2006).

- Zakon o javnih uslužbencih (Uradni list RS, št. 32/2006- prečiščeno besedilo, št. 33/2007)

- Zakon o sodelovanju delavcev pri upravljanju, uradno prečiščeno besedilo (Uradni list RS, št. 42/2007).

- Act XX. of 1949. Hungarian Constitution, article 63 and 70/C

- Act XXXIII of 1992. About public service employees, Issued in Official Journal

- Magyar Közlöny 1992/56 (VI. 2.)

- Act XXIII of 1992. About civil servants, Issued in Official Journal:

- Magyar Közlöny 1992/46 (V.5.)

- Act XLIII of 1996. About service and armed forces, Issued in Official Journal:

- Magyar Közlöny 1996/44 (VI. 6.)

- Act XCV of 2001. About service at armed forces, Issued in Official Journal:

- Magyar Közlöny 2001/146 (XII. 17.)

- $\quad$ Act XXII of 1992. Labour Code, Issued in Official Journal:

- Magyar Közlöny 1992/45 (V. 4.) 


\section{Zvone Vodovnik, Aniko Noemi Turi}

\section{Social Dialogue in Public Sector}

Reflection about Hungarian and Slovenian approach

- $\quad$ http://www.mszosz.hu/eucsatl/szocialis.html (National Associations of Hungarian Trade Unions) date: 27. 05. 2008.

- $\quad$ http://www.szmm.gov.hu (Ministry of Social Affaires and Labour) date: 27. 05. 2008.

- $\quad h t t p: / / w w w . s z m m . g o v . h u / m a i n . p h p ? f o l d e r l D=10006$ (Information related to social dialogue) date: 27. 05. 2008.

- $\quad$ http://szmm.gov.hu/main.php?folderlD=13879\&articlelD=22312\&ctag=articlelist\&ii $\mathrm{d}=1$ (Labour Mediatory and Arbitral Conciliation) date: 27. 05. 2008.

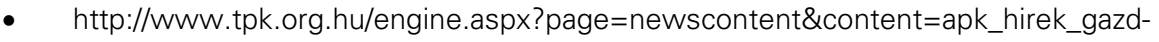
szoc_tanacs (Centre of Social Dialogue) date: 28. 05. 2008.

- http://www.ugyvezeto.hu/?fejezet=5\&alfejezet=0\&tartalom=0\&cid=30397\&wa=eh um0713h (Article about the regulation of strike) 30. 05. 2008.

- $\quad$ http://www.eurofound.europa.eu date: 22. 05. 2008

- $\quad$ http://www.ilo.org/public/english/dialogue/actemp/papers/1998/srscbarg.htm (about collective bargaining) date: 26. 05. 2008.

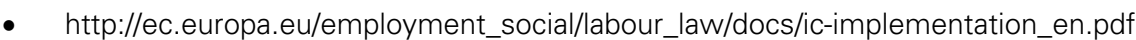
(about the national implementation of Directive 2002/14/EC date: 26. 05. 2008.

- http://ec.europa.eu/growthandjobs/pdf/2006_annual_report_hungary_en.pdf date: 26.05.2008.

- $\quad$ http://ec.europa.eu/growthandjobs/pdf/nrp2007/HU_nrp_en.pdf date: 26. 05. 2008.

- $\quad$ http://www.nfu.hu/?lang=en (website of National Development Agency in Hungary) date: 28. 05. 2008.

- $\quad$ http://www.worker-participation.eu date: 30. 05. 2008.

- $\quad$ http://www.arbetsdomstolen.se date: 07. 06.2008.

- http://www.legislationline.org/upload/legislations/aa/0e/cf4f2ba2a849cd3ac7dd08e8 8b76.pdf date: 08.06.2008. 


\section{SOCIALNI DIALOG V JAVNEM SEKTORJU}

\section{RAZMISLEK O NEKATERIH MADŽARSKIH IN SLOVENSKIH ZNAČILNOSTIH}

Socialni dialog je pomembna družbena komunikacija med socialnimi partnerji, ki kot subjekti civilne družbe vedno bolj prevzemajo nekatere vloge države na regulatornem področju. To velja za nacionalne pravodajne procese kot tudi za mednarodne. V Evropski uniji je socialnemu dialogu namenjeno vedno več pozornosti, čeprav to področje ni $v$ ospredju zakonodajnih aktivnosti organov te mednarodne zveze. Socialni dialog je obravnavan kot eeden izmed pomembnih motivacijskih sredstev, s pomočjo katerih je mogoče spodbujati zaposlene $\mathrm{k}$ boljšemu delu in ustvarjalnosti in $\mathrm{s}$ tem prispevati $k$ uveljavljanju cilja pospešenega gospodarskega razvoja. To naj omogoči, da bo evropsko gospodarstvo postalo bolj konkurenčno in prožno na svetu. Članek obravnava socialni dialog in njegovo pravno urejenost $v$ Evropski uniji in $v$ dveh njenih članicah, to je $v$ Sloveniji in na Madžarskem. Pri tem se omejuje na kratek prikaz glavnih značilnosti tega pojava $v$ obeh pravnih ureditvah, podrobneje pa obravnava značilnosti socialnega dialoga $v$ javnem sektorju.

Socialni dialog sorazmerno dolgo ni bil osrednji predmet pozornosti organov Evropske unije. Med glavnimi razlogi za to je dejstvo, da je tematika socialnega dialoga tesno povezana z zgodovino, tradicijo in kulturo držav članic, ki so zelo različne in heterogene. Te različnosti so dolgo zadrževale možnost, kakršne koli uveljavitve pravnih aktov, ki bi urejali to tematiko na evropski ravni. Širitev Evropske unije je še poglobila razlike $v$ modelih, uveljavljenih $v$ posameznih državah in še dodatno otežila učinkovito pravno urejanje te tematike na evropski ravni.

Na zakonodajne aktivnosti organov EU vplivajo ob nacionalnih ureditvah tudi akti univerzalnih mednarodnih organizacij, $v$ obravnavanem primeru zlasti akti Mednarodne organizacije dela (ILO). Gre zlasti za konvencije MOD o delovnih razmerjih zaposlenih $v$ javnem sektorju. Ti mednarodno pravni akti usmerjajo države, da prenašajo nekatere svoje pristojnosti za urejanje delovnih razmerij na institucije civilne družbe, torej socialne partnerje. Na teh aktih temelji tudi pomembno načelo, da je treba interesne spore med socialnimi partnerji, če je le mogoče, preprečevati in razreševati z uporabo "mehkih" metod oziroma brez intervence državnih organov. Na širšem 
Zvone Vodovnik, Aniko Noemi Turi

Social Dialogue in Public Sector

Reflection about Hungarian and Slovenian approach

področju urejanja delovnih razmerij so organi EU doslej razvili sorazmerno skromno področje pravil, ki omogočajo socialni dialog. Večina tem, ki so neposredno povezane s socialnim dialogom je namreč $v$ izključni pristojnosti organov držav članic, torej je po pravilih EU izključena iz pravnega urejanja na nadnacionalni ravni. Izjema pa je tematika pravne ureditve obveščanja in skupnih posvetovanj z delavskimi predstavniki in širša tematika sodelovanja zaposlenih pri odločanju. Ta mednarodno pravna ureditev je vplivala na zakonodajne postopke tako na Madžarskem kot tudi v Sloveniji. Na področju javnega sektorja, kjer je vpliv mednarodnopravnih pravil manjši, je na Madžarskem uveljavljen sistem kolektivnih pogajanj $v$ javnem sektorju, ob tem pa so se $v$ tej državi uveljavili tudi organi za preprečevanje in odpravljanje sporov med socialnimi partnerji v tem sektorju. Tudi v Sloveniji obstaja razvit socialni dialog $v$ javnem sektorju. Na graditev tega sistema pomembno vpliva spreminjanje njegove strukture, na primer - uveljavljanje pokrajin. Kolektivna pogajanja $v$ tem sektorju niso povsem prosta, ker zakon predpostavlja nujnost ureditve nekaterih vprašanj s kolektivnimi pogodbami. $\checkmark$ obeh državah je $v$ ospredju pozornosti vprašanje iskanja najprimernejšega načina preprečevanja in razreševanja interesnih sporov med socialnimi partnerji. Na Madžarskem so za te namene ustanovljeni posebni organi, ki imajo značaj organov mediacije. Takšna ureditev bi bila primerna tudi $v$ Sloveniji, vendar zanjo zaenkrat ni neposredne pravne podlage, ker splošna zakonska pravila o kolektivnih pogajanjih in preprečevanju in razreševanju sporov, ki vključujejo ta pravila, ne veljajo za javni sektor. 